\title{
Nutritional value of glycerin for pigs determined by different methodologies
}

\section{Guiomar Helena Verussa ${ }^{1}$, Anderson Corassa ${ }^{1 *}$, Douglas dos Santos Pina ${ }^{1}$, Ana Paula Silva Ton ${ }^{1}$, Cláudia Marie Komiyama ${ }^{1}$, Alexandre de Oliveira Teixeira ${ }^{2}$}

\author{
${ }^{1}$ Universidade Federal de Mato Grosso, Instituto de Ciências Agrárias e Ambientais, Sinop, MT, Brazil \\ ${ }^{2}$ Universidade Federal de São João del-Rei, Departamento de Zootecnia, São João del-Rei, MG, Brazil.
}

\begin{abstract}
The objective of this study was to determine the nutritional value of glycerin for pigs using different inclusion levels of this test ingredient and the methodologies of total collection and chromium oxide marker. Eight barrows were distributed individually into metabolic cages, in a randomized-block experimental design, and fed diets containing 0,50 , 100 , and $150 \mathrm{~g} \mathrm{~kg}^{-1}$ plant-derived crude glycerin. The feed digestibility methodologies of total feces and urine collection and chromium oxide marker were analyzed. Inclusion of up to $150 \mathrm{~g} \mathrm{~kg}^{-1}$ crude glycerin improved the digestibility coefficients of organic matter and energy of the diets. The collection method based on the use of chromium oxide marker underestimates the digestibility coefficient of ash and the energy values of glycerin in relation to the total collection method, but yields similar results to those obtained with the total collection method for the dry matter, organic matter, crude protein, ether extract, and neutral detergent fiber assessed.
\end{abstract}

Key Words: biodiesel, digestibility, glycerol, marker, metabolizability, total feces collection

\section{Introduction}

The use of glycerin, a byproduct from biodiesel production, in the feeding of swine is an option that has been investigated due to its considerable energy content similar to that of corn, in addition to being considered palatable for its sweetish taste (Groesbeck et al., 2008). For these reasons, it can positively affect the performance of piglets.

Glycerin has been employed as a source of readily available energy because of its rapid absorption in the intestine and easy metabolization in the liver; thus, it can be made available for the formation of lipids or production of energy through glycolysis and the citric acid cycle (Gallego et al., 2014). The use of glycerin in swine feeding also casts doubts as to the adequate level of its inclusion in the different production stages; for example, $120 \mathrm{~g} \mathrm{~kg}^{-1}$ for 15 to $30 \mathrm{~kg}$ (Carvalho et al., 2012), $150 \mathrm{~g} \mathrm{~kg}^{-1}$ for 27 to $48 \mathrm{~kg}$ (Verussa et al., 2017), $160 \mathrm{~g} \mathrm{~kg}^{-1}$ for 67 to $107 \mathrm{~kg}$ (Gomide et al., 2012), $150 \mathrm{~g} \mathrm{~kg}^{-1}$ for 97 to $115 \mathrm{~kg}$

Received: August 27, 2016

Accepted: April 18, 2017

*Corresponding author: anderson_corassa@ufmt.br

http://dx.doi.org/10.1590/S1806-92902017000700005

How to cite: Verussa, G. H.; Corassa, A.; Pina, D. S.; Ton, A. P. S.; Komiyama, C. M. and Teixeira, A. O. 2017. Nutritional value of glycerin for pigs determined by different methodologies. Revista Brasileira de Zootecnia 46(7):584-590.

Copyright (c) 2017 Sociedade Brasileira de Zootecnia. This is an Open Access article distributed under the terms of the Creative Commons Attribution License (http://creativecommons.org/licenses/by/4.0/), which permits unrestricted use, distribution, and reproduction in any medium, provided the original work is properly cited.
(Leite et al., 2017). However, studies aimed at analyzing the addition of glycerin in swine nutrition, considering its digestibility (Gallego et al., 2014; Madrid et al., 2013), are of paramount importance. In vivo trials are conducted to estimate digestibility coefficients of nutrients and mainly to determine the metabolizable energy contents of feedstuffs. The most widely used methods for digestibility trials are total feces and urine collection and markers, whereby chromium oxide is one of the most used in digestibility trials for pigs.

For Sakomura and Rostagno (2007), the main limitation of the total collection method is the control during collection of feces and urine samples without contaminations such as shedding of skin, hair, and feed, which may interfere with the determination of the energy content of a feedstuff. On the other hand, the use of markers does not require quantification of intake and feces and a partial collection of the sample can be performed decreasing possible contamination. However, the use of this method requires uniform mixture into the diet and standardization for chemical analyses, which may lead to a significant variability of results.

Therefore, the objective of this study was to determine the nutritional value of glycerin for pigs using different inclusion levels of the test ingredient and the total collection and marker methodologies.

\section{Material and Methods}

The experiment was conducted in the city of Sinop,

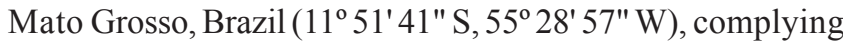


with the ethical principles of animal experimentation adopted by the Conselho Nacional de Controle de Experimentação Animal and after being approved by the Ethics Committee in Animal Use (case no. 23108.700673/14-4). Eight genetically homogeneous barrows from industrial crosses, with an average initial weight of $31.08 \pm 3.73 \mathrm{~kg}$, were distributed individually into eight metabolic cages, in a randomized block experimental design consisting of four treatments and six replications, with each animal as an experimental unit. The replications were obtained over three experimental periods. The formation of blocks took into consideration the weight of the animals and the period. Each experimental period lasted 10 days, with five days for adaptation of the animals to the metabolic cages and diets and five days for feces and urine collection.

Treatments were composed of a corn- and soybeanmeal-based diet (Table 1), formulated so as to meet the recommendations of Rostagno et al. (2011), and with soy oil-based glycerin in an isometric replacement of 50, 100, and $150 \mathrm{~g} \mathrm{~kg}^{-1}$ of the diet according to the methodology described by Sakomura and Rostagno (2007). The glycerin used in this study contained 4.9, 865.0, 0.50 , and $3.0 \mathrm{~g} \mathrm{~kg}^{-1}$ as fed and 5,397 $\mathrm{kcal} \mathrm{kg}^{-1}$ water, glycerol, methanol, total fatty acids, and gross energy, respectively (Bunge Alimentos, Nova Mutum, MT, Brazil). To add the glycerin in both treatments, it was pre-mixed with approximately $200 \mathrm{~g} \mathrm{~kg}^{-1}$ of the total amount of the feed aiming to improve the final uniformity. To obtain the chemical composition

Table 1 - Composition and calculated nutritional values of control diet (as-fed basis)

\begin{tabular}{lc}
\hline Ingredient $\left(\mathrm{g} \mathrm{kg}^{-1}\right)$ & Control diet \\
\hline Corn & 604.8 \\
Soybean meal & 302.6 \\
Rice bran & 30.0 \\
Soy oil & 18.9 \\
Calcitic limestone & 5.2 \\
Dicalcium phosphate & 17.5 \\
Vitamin-mineral mix & 10.0 \\
Common salt & 4.6 \\
L-lysine & 1.5 \\
Chromium oxide & 5.0 \\
Total & 1000 \\
Calculated nutrient content $\left(\mathrm{g} \mathrm{kg}^{-1}\right)$ & \\
Metabolizable energy $\left({\left.\mathrm{kcal} \mathrm{kg}^{-1}\right)}^{\text {Crude protein }}\right.$ & 3,230 \\
Calcium & 189.9 \\
Available phosphorus & 7.2 \\
Sodium & 3.6 \\
Digestible lysine & 2.0 \\
\hline
\end{tabular}

${ }^{1}$ Composition of the supplement per kg of diet: vitamin A, 13750 IU; vitamin B1, $2 \mathrm{mg}$; vitamin B2, $1.25 \mathrm{mg}$; vitamin B6, $4 \mathrm{mg}$; vitamin B12, $4.5 \mathrm{mcg}$; vitamin D3, $3000 \mathrm{UI}$; vitamin E, $75 \mathrm{IU}$; vitamin $\mathrm{K} 3,6.25 \mathrm{mg}$; nicotinic acid, $50 \mathrm{mg}$; pantothenic acid, $30 \mathrm{mg}$; folic acid, $0.625 \mathrm{mg}$; cobalt, $1.25 \mathrm{mg}$; copper, $25 \mathrm{mg}$; iron, $150 \mathrm{mg}$; zinc, $200 \mathrm{mg}$; manganese, $75 \mathrm{mg}$; selenium, $0.7 \mathrm{mg}$; iodine, $2 \mathrm{mg}$; coline, $250 \mathrm{mg}$; biotin, $25 \mathrm{mcg}$. of the diets, the dry matter (DM), crude protein (CP), ash, ether extract (EE), neutral detergent fiber (NDF), and gross energy (GE) were analyzed as described by Detmann et al. (2012) (Table 2).

In the period of adaptation, the feed was supplied ad libitum and refusals were counted for a later calculation of intake based on the metabolic weight $\left(\mathrm{LW}^{0.75}\right)$. To avoid losses and facilitate ingestion, diets were weighed and moistened at the ratio of $1: 1$ and provided twice daily $(07.30$ and $17.30 \mathrm{~h})$. Two methodologies for evaluation of nutrient digestibility were used: total feces collection and digestibility marker. Chromium oxide $\left(\mathrm{Cr}_{2} \mathrm{O}_{3}\right)$ was used as the digestibility marker in the second methodology.

For the digestibility trial, the methods of total feces and urine collection and chromium oxide marker were used simultaneously. Feces and urine were collected once daily, in the morning. Feces were collected, weighed, homogenized, and then samples of $200 \mathrm{~g} \mathrm{~kg}^{-1}$ of the total were taken, packed in plastic bags, labeled, and stored in a freezer $\left(-10^{\circ} \mathrm{C}\right)$ until the end of the collection period. The urine was filtrated as it was excreted, using a filter fabric coupled to the funnel of the urine collection box, and then collected into plastic buckets containing $10 \mathrm{~mL} \mathrm{HCl} \mathrm{1:1.}$ The total urine volume of each animal was counted using a beaker with $5-\mathrm{mL}$ graduation, from which samples of $200 \mathrm{~g} \mathrm{~kg}^{-1}$ were taken for sampling, which were packed in plastic packages with lid and stored in a freezer.

At the end of the collection period, diets and feces samples were thawed, weighed, homogenized, and predried in a forced-air oven at $60{ }^{\circ} \mathrm{C}$ for $72 \mathrm{~h}$ for analyses of $\mathrm{DM}, \mathrm{CP}$, ash, EE, NDF, and GE, according to Detmann et al. (2012). The organic matter (OM) content was determined as the difference between the dry matter and ash contents. Chromium in the diets and feces was analyzed by atomic absorption spectrophotometry. Urine samples were thawed and homogenized for determination of total nitrogen. The GE values of the samples were obtained using a bomb calorimeter.

Table 2 - Chemical composition of diets

\begin{tabular}{|c|c|c|c|c|}
\hline \multirow{2}{*}{ Item ( $\mathrm{g} \mathrm{kg}^{-1}$ dry matter $)$} & \multicolumn{4}{|c|}{ Glycerin level ${ }^{1}\left(\mathrm{~g} \mathrm{~kg}^{-1}\right)$} \\
\hline & 0 & 50 & 100 & 150 \\
\hline Dry matter & 899.9 & 891.6 & 880.0 & 885.2 \\
\hline Organic matter & 897.6 & 898.4 & 910.7 & 910.1 \\
\hline Crude protein & 209.7 & 194.8 & 191.8 & 178.6 \\
\hline Ether extract & 40.9 & 40.7 & 38.2 & 37.2 \\
\hline Ash & 102.4 & 101.6 & 96.9 & 89.9 \\
\hline Neutral detergent fiber & 147.4 & 139.4 & 137.9 & 130.0 \\
\hline Gross energy $\left(\mathrm{kcal} \mathrm{kg}^{-1}\right)$ & 3,943 & 3,980 & 3,988 & 3,992 \\
\hline
\end{tabular}

R. Bras. Zootec., 46(7):584-590, 2017 
The digestibility coefficients (DC), concentrations of digestible nutrients, and digestible energy (DE) and metabolizable energy (ME) values and their correction for nitrogen content $\left(\mathrm{DE}_{\mathrm{N}}\right.$ and $\left.\mathrm{ME}_{\mathrm{N}}\right)$ were determined by equations given in Sakomura and Rostagno (2007). Animals were weighed at the beginning and end of each period and the feed intake was recorded for the calculation of daily feed intake, daily weight gain, and feed conversion of each experimental unit. The experiment was conducted in a randomized-block design in a split-plot arrangement and an analysis of variance was performed according to the model below:

$$
\text { Yijk }=\mu+\mathrm{Gi}+\mathrm{Pj}+\mathrm{Mk}+\mathrm{Gi} \times \mathrm{Mk}+\varepsilon \mathrm{ij}+\varepsilon \mathrm{ijk},
$$

in which Yijk = observation of the effect of glycerin level $\mathrm{i}$ in period $\mathrm{j}$ by digestibility assessment method $\mathrm{k} ; \mu=$ overall mean; $\mathrm{Gi}=$ effect of glycerin inclusion level $\mathrm{i}$ $\left(\mathrm{i}=0,50,100\right.$, and $\left.150 \mathrm{~g} \mathrm{~kg}^{-1}\right) ; \mathrm{Pj}=$ experimental period $\mathrm{j}$ $(\mathrm{j}=1,2$, and 3$) ; \mathrm{Mk}=$ effect of digestibility assessment method $\mathrm{k}(\mathrm{k}=$ total collection and marker); $\mathrm{Gi} \times \mathrm{Mk}=$ effect of the interaction between glycerin level i and digestibility assessment method $\mathrm{k}$; $\varepsilon \mathrm{ij}=$ random error associated with the plot; and $\varepsilon i j \mathrm{k}=$ random error associated with the sub-plot.

The effects related to the glycerin levels were evaluated by breaking down the sum of treatment squares into orthogonal contrasts to evaluate the linear and quadratic effects. The $\mathrm{F}$ test was used to evaluate the collection methods. Both evaluations were undertaken considering a probability of $\mathrm{P}<0.05$ for type-I error, with data subjected to the MIXED procedure of SAS software (Statistical Analysis System, version 6.0). For the performance analysis, the initial weight was used as a co-variable. Data of digestibility and metabolizability coefficients, $\mathrm{DE}_{\mathrm{N}}$, and $\mathrm{ME}_{\mathrm{N}}$ corrected for the nitrogen excretion from diets and of glycerin were subjected to an ANOVA considering the effects of the of digestibility assessment methodology and the interaction between them and glycerin levels. The ME value was estimated by regression analysis (Adeola and
Ileleji, 2009) of ME intake (kcal) associated of glycerin vs. glycerin intake ( $\mathrm{g}$ ) by total collection (TC) and chromium marker (Cr).

\section{Results}

The animal performance during the digestibility trial was not affected by the addition of up to $150.0 \mathrm{~g} \mathrm{~kg}^{-1}$ crude glycerin (Table 3 ).

The digestibility coefficients of DM and OM improved linearly as the glycerin inclusion level was increased (Table 4). The DC of CP, EE, and NDF did not differ as a function of the increased glycerin inclusion levels. There were no differences for DC of DM, OM, CP, EE, and NDF as a function of the digestibility methods. The chromium oxide marker method provided lower DC of ash in relation to the total collection method; i.e., the marker method may have underestimated these values. There was an interaction between glycerin levels and collection methods for the DC of ash. The DC of ash increased linearly with the glycerin level as evaluated by the total collection method $(\hat{Y}=89.4978-0.3502 \times \mathrm{GL} ; \mathrm{P}=0.0347$; $\left.\mathrm{R}^{2}=0.1054\right)$, whereas the marker method had a quadratic $\operatorname{effect}(\hat{\mathrm{Y}}=74.2542-1.5291 \times \mathrm{GL}+0.1042 \times \mathrm{GL} 2 ; \mathrm{P}=0.0065$; $\left.\mathrm{R}^{2}=0.3199\right)$.

The inclusion of up to $150 \mathrm{~g} \mathrm{~kg}^{-1}$ of the test ingredient did not influence the determination of glycerin energy values. The chromium oxide marker method resulted in the lowest $\mathrm{DE}, \mathrm{DE}_{\mathrm{N}}, \mathrm{ME}$, and $\mathrm{ME}_{\mathrm{N}}$ values and the highest $\mathrm{ME}$ : $D E$ ratio of crude glycerin in relation to the total collection method. The $\mathrm{ME}_{\mathrm{N}}: \mathrm{DE}_{\mathrm{N}}$ ratio was the same for both methods (Table 5).

The average DE of glycerin did not differ among the treatments. The slope of the linear relationship between metabolizable energy intake and glycerin intake (Figure 1) show that total collection (TC) and chromium marker (Cr) generated similar ME (3,272 and 3,263 kcal kg-1, respectively).

Table 3 - Initial weight, final weight, daily weight gain (DWG), daily feed intake (DFI), and feed conversion (FC) of pigs fed diets with different glycerin levels during the digestibility trial

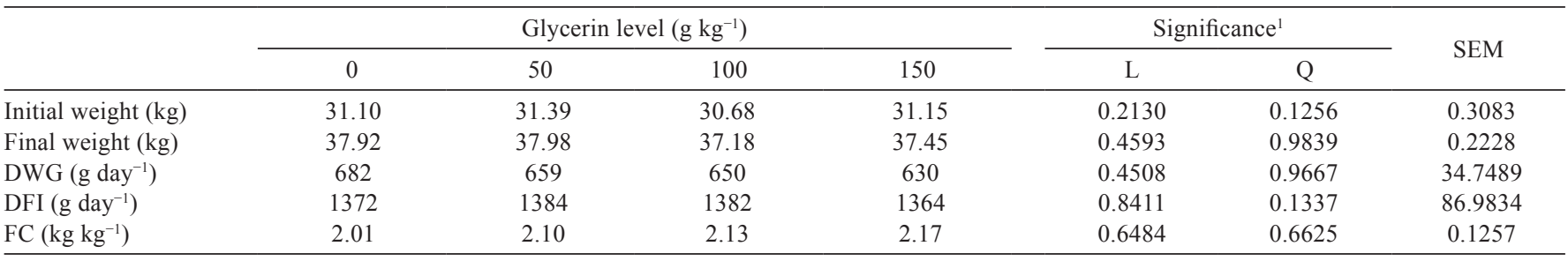

${ }^{1}$ Significance level at $\mathrm{P}<0.05$.

L - linear effect; Q - quadratic effect; SEM - standard error of the mean. 


\section{Discussion}

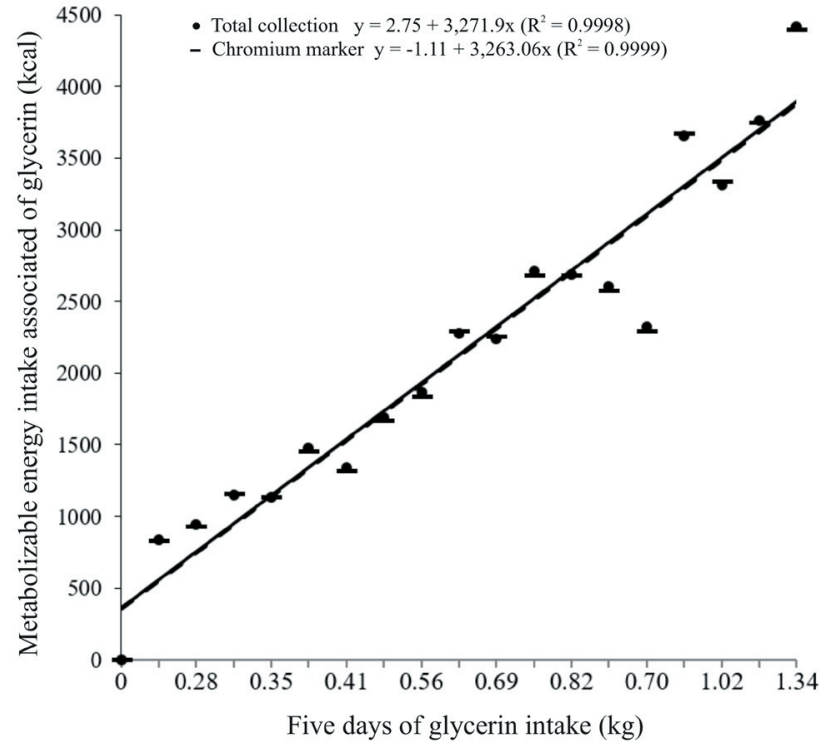

Figure 1 - Equations of metabolizable energy of glycerin obtained from intake of metabolizable energy $\left(\mathrm{kcal} \mathrm{kg}^{-1}\right)$, associated to glycerin vs. glycerin intake (g) during five days determined by the total collection and chromium marker digestibility methodologies.
The performance results demonstrate that glycerin can be used at levels up to $150 \mathrm{~g} \mathrm{~kg}^{-1}$ without impairing performance. Working with piglets in the starter phase with up to four glycerin inclusion levels $(30,60,90$, and $120 \mathrm{~g} \mathrm{~kg}^{-1}$ ), Gonçalves et al. (2013) also did not find differences in animal performance. Likewise, Gallego et al. (2014) did not find differences in the performance of piglets fed diets with glycerin levels up to $140 \mathrm{~g} \mathrm{~kg}^{-1}$.

The lack of an effect of glycerin levels on daily feed intake in the present study indicates that this ingredient did not improve the palatability of the feed, contrasting the findings of Groesbeck et al. (2008), who observed a trend towards increased feed intake and weight gain of animals consuming increasing levels of glycerin $(0,30,60,90$, and $150 \mathrm{~g} \mathrm{~kg}^{-1}$ ) due to its sweetish taste.

However, Zijlstra et al. (2009), who evaluated three glycerin levels $\left(0,40\right.$, and $\left.80 \mathrm{~g} \mathrm{~kg}^{-1}\right)$ in the feeding of newly weaned pigs, found that pigs fed $40 \mathrm{~g} \mathrm{~kg}^{-1}$ glycerin had a higher feed intake than the animals that received the other

Table 4 - Digestibility coefficients (DC) of the chemical composition of pig experimental diets with different glycerin levels determined by the total collection (TC) and chromium marker (Cr) digestibility methodologies

\begin{tabular}{|c|c|c|c|c|c|c|c|c|c|c|c|}
\hline \multirow{2}{*}{$\begin{array}{l}\mathrm{DC} \\
\left(\mathrm{g} \mathrm{kg}^{-1} \mathrm{DM}\right)\end{array}$} & \multicolumn{4}{|c|}{ Glycerin level $\left(\mathrm{g} \mathrm{kg}^{-1}\right)$} & \multicolumn{2}{|c|}{ Digestibility methodology } & \multirow[b]{2}{*}{$\mathrm{M} \times \mathrm{GL}$} & \multicolumn{3}{|c|}{ Significance $^{1}$} & \multirow[b]{2}{*}{ SEM } \\
\hline & 0 & 50 & 100 & 150 & $\mathrm{TC}$ & $\mathrm{Cr}$ & & $\mathrm{L}$ & Q & $\begin{array}{l}\text { Digestibility } \\
\text { methodology }\end{array}$ & \\
\hline DM & 859.0 & 861.9 & 872.4 & 889.0 & 873.9 & 867.1 & 0.2334 & 0.0413 & 0.2895 & 0.0873 & 16.9176 \\
\hline OM & 873.3 & 876.7 & 886.5 & 902.3 & 887.6 & 881.9 & 0.2176 & 0.0405 & 0.3235 & 0.0916 & 4.5870 \\
\hline $\mathrm{CP}$ & 843.0 & 845.6 & 841.2 & 857.9 & 850.6 & 843.2 & 0.2373 & 0.8841 & 0.5224 & 0.1151 & 6.3619 \\
\hline $\mathrm{EE}$ & 714.6 & 710.3 & 723.6 & 733.6 & 713.1 & 728.0 & 0.4215 & 0.7056 & 0.8114 & 0.1415 & 25.2678 \\
\hline Ash & 810.1 & 804.6 & 798.4 & 807.9 & 876.3 & 734.3 & 0.0348 & 0.5675 & 0.5473 & $<0.0001$ & 16.6015 \\
\hline NDF & 608.9 & 616.4 & 645.3 & 621.7 & 613.6 & 632.6 & 0.5826 & 0.1906 & 0.4045 & 0.2842 & 24.2414 \\
\hline
\end{tabular}

DM - dry matter; OM - organic matter; CP - crude protein; EE - ether extract; NDF - neutral detergent fiber; GL - glycerin level; M $\times$ GL - digestibility methodology $\times$ glycerin level interaction; L - linear effect; Q - quadratic effect; SEM - standard error of the mean.

${ }^{1}$ Significance level at $\mathrm{P}<0.05$.

$\hat{\mathrm{Y}}_{\mathrm{DC}-\mathrm{DM}}=85.5197+0.2049 \times \mathrm{GL}\left(\mathrm{R}^{2}=0.35\right) ; \hat{\mathrm{Y}}_{\mathrm{DC}-\mathrm{OM}}=87.4649+0.1416 \times \mathrm{GL}\left(\mathrm{R}^{2}=0.18\right)$

Table 5 - Energy-related variables of glycerin determined by the total collection (TC) and chromium marker (Cr) digestibility methodologies

\begin{tabular}{|c|c|c|c|c|c|c|c|c|c|c|}
\hline & \multicolumn{3}{|c|}{ Glycerin level $\left(\mathrm{g} \mathrm{kg}^{-1}\right)$} & \multicolumn{2}{|c|}{ Digestibility methodology } & \multirow[b]{2}{*}{$\mathrm{M} \times \mathrm{GL}$} & \multicolumn{3}{|c|}{ Significance $^{1}$} & \multirow[b]{2}{*}{ SEM } \\
\hline & 50 & 100 & 150 & $\mathrm{TC}$ & $\mathrm{Cr}$ & & $\mathrm{L}$ & Q & $\begin{array}{l}\text { Digestibility } \\
\text { methodology }\end{array}$ & \\
\hline $\mathrm{DE}\left(\mathrm{kcal} \mathrm{kg}^{-1}\right)$ & 3,387 & 3,387 & 3,388 & 3,405 & 3,370 & 0.5994 & 0.9059 & 0.9601 & $<0.0001$ & 0.0046 \\
\hline $\mathrm{DE}_{\mathrm{N}}\left(\mathrm{kcal} \mathrm{kg}^{-1}\right)$ & 3,374 & 3,374 & 3,374 & 3,392 & 3,357 & 0.5970 & 0.9261 & 0.9458 & $<0.0001$ & 0.0045 \\
\hline $\operatorname{ME}\left(\mathrm{kcal} \mathrm{kg}^{-1}\right)$ & 3,270 & 3,270 & 3,271 & 3,280 & 3,261 & 0.8343 & 0.8800 & 0.9933 & 0.0094 & 0.0079 \\
\hline $\mathrm{ME}_{\mathrm{N}}\left(\mathrm{kcal} \mathrm{kg}^{-1}\right)$ & 3,258 & 3,258 & 3,259 & 3,269 & 3,248 & 0.8339 & 0.8884 & 0.9962 & 0.0037 & 0.0078 \\
\hline ME:DE ratio & 0.9652 & 0.9654 & 0.9654 & 0.9631 & 0.9676 & 0.9917 & 0.9328 & 0.9802 & 0.0257 & 0.0022 \\
\hline $\mathrm{ME}_{\mathrm{N}}: \mathrm{DE}_{\mathrm{N}}$ ratio & 0.9656 & 0.9658 & 0.9658 & 0.9639 & 0.9676 & 0.9911 & 0.9305 & 0.9769 & 0.0597 & 0.0022 \\
\hline
\end{tabular}

$\mathrm{DE}$ - digestible energy; $\mathrm{DE}_{\mathrm{N}}$ - digestible energy corrected for nitrogen balance; $\mathrm{ME}$ - metabolizable energy; $\mathrm{ME}_{\mathrm{N}}$ - metabolizable energy corrected for nitrogen balance; $\mathrm{M} \times \mathrm{GL}$ Digestibility methodology $\times$ glycerin level interaction; L - linear effect; $\mathrm{Q}$ - quadratic effect; SEM - standard error of the mean.

${ }^{1}$ Significance level $\mathrm{P}<0.05$. 
diets. Similarly, Rocha (2013) replaced powder milk whey by glycerin at the levels of 0,90 , and $180 \mathrm{~g} \mathrm{~kg}^{-1}$ for piglets and found that the animals fed $90 \mathrm{~g} \mathrm{~kg}^{-1}$ glycerin consumed more than the others. Researchers of both studies suggested that glycerin inclusion might have improved the palatability of the feed and consequently increased intake, but only to a certain extent, given that the decreased intake with the diets containing higher glycerin contents might have been due to a possible increase in the energy content of that diet.

The DC values evaluated, irrespective of the digestibility assessment method, show that glycerin can be considered a highly digestible feedstuff for pigs in the starter phase and that, as the glycerin inclusion in the diet increases up to $150 \mathrm{~g} / \mathrm{kg}$, there is an increase in the digestibility of the fractions of DM and OM. The equations generated to predict values indicated that changing $10 \mathrm{~g} \mathrm{~kg}^{-1}$ glycerin in diet will result in DC difference of 2.049 and $1.416 \mathrm{~g} \mathrm{~kg}^{-1}$ of DM and OM on an as-fed basis, respectively. Comparing the results found in this experiment with the DC of corn, according to Rostagno et al. (2011), with 850, 664, and $900 \mathrm{~g} \mathrm{~kg}^{-1}$ dry matter for $\mathrm{CP}, \mathrm{NDF}$, and $\mathrm{OM}$, respectively, a similarity is observed, which emphasizes the possibility of substituting the corn for glycerin in the feeding of pigs without causing losses in the digestibility of these nutrients. The DC of DM and OM increased with the addition of glycerin to the diet, which may be explained by the fact that glycerin inclusion also represents an indirect addition of organic matter, which includes EE, and this might have led to better use of these nutrients. Madrid et al. (2013) worked with inclusion of up to $50 \mathrm{~g} \mathrm{~kg}^{-1}$ glycerin in growing pig diets and also found an increasing linear effect on the DC of OM with the glycerin inclusion levels; these values were above $870 \mathrm{~g} \mathrm{~kg}^{-1} \mathrm{DM}$.

The DC of NDF was not influenced by different glycerin inclusion levels, differing from Hanczakowska et al. (2010), who found an improvement in the fiber digestibility after including $100 \mathrm{~g} \mathrm{~kg}^{-1}$ glycerin compared with control treatment, in diets for pigs from 30 to $100 \mathrm{~kg}$. The authors suggested that the better fiber digestibility may stem from a bacterial fermentation in the intestine due to the possibility of glycerol reaching the colon and cecum and stimulating the development of fiber-degrading microorganisms; however, this does not seem to have occurred in the present study, perhaps due to the shorter intake time of the glycerin.

The variability of results related to the chromium oxide method as compared with total collection is explained by Sakomura and Rostagno (2007), especially because of the possibility that chromium oxide is being fully retrieved in the feces, which interferes with the indigestibility factor used for the calculations of digestibility. The striking variation of its excretion in the feces (Hopper et al., 1978) and incomplete fecal recuperation (Soares et al., 2004), attributed to differences of kind and quality of diet (Ribeiro Filho et al., 2008), are characteristics of the use of chromium oxide.

The underestimated DC of ash obtained using chromium oxide in this study may be explained by the possible interference of chromium in the absorption of other minerals like calcium and phosphorus (Fernandez et al., 1999). However, Kavanagh et al. (2001) recorded fecal marker recovery of $960 \mathrm{~g} \mathrm{~kg}^{-1}$ for $\mathrm{Cr}_{2} \mathrm{O}_{3}$, but DM and energy digestibility coefficients were not different for total collection. Therefore, it is understood that the quantification of the indicator in feed and feces is an essential condition for the use of the technique, so as not to estimate the values included in the diets. According to Kavanagh et al. (2001), by using the assumed concentration of marker in the diet, the assumption is made that the marker is dispersed correctly through the feed, but the marker can be lost at the mixing stage, particularly if a mill is being used; however, the measured concentration in the diet is more accurate, particularly when the same sampling procedure and laboratory analysis has been perfected over a long period of time to ensure accurate sampling.

As the differences in DC between the digestibility methods were small, except for the ash, it was not possible to identify significant statistical differences. Inversely, Agudelo et al. (2010) recorded values of digestibility for $\mathrm{DM}$, energy, and $\mathrm{N}$ that were 2-3 percentage points lower by chromium oxide vs. total collection and considered that digestibility differences between methods were smaller for highly digestible, highly concentrated nutrients, implying that indicator method could be less able to detect differences. Gobesso et al. (2011), on the other hand, stated that chromium oxide represents the most precise marker method for apparent digestibility in horses compared with the internal markers acid detergent lignin and acid detergent insoluble ash. Similarly to the present study, Nunes (2012) found that the DC of the chromium oxide marker differed from those of the titanium oxide and purified lignin markers and total collection methods, underestimating the digestibility of pig diets.

The average DE of glycerin was $3,387 \mathrm{kcal} \mathrm{kg}^{-1}$, which is higher than the $3,298 \mathrm{kcal} \mathrm{kg}^{-1}$ found by Gallego et al. (2014) for semi-purified ( $800 \mathrm{~g} \mathrm{~kg}^{-1}$ glycerol) glycerin for piglets in the starter phase, and the $3,344 \mathrm{kcal} \mathrm{kg}^{-1}\left(870 \mathrm{~g} \mathrm{~kg}^{-1}\right.$ glycerol) reported by Lammers et al. (2008).

The ME values of glycerin were close to those recorded by Gonçalves et al. (2013) $\left(3,373 \mathrm{kcal} \mathrm{kg}^{-1}\right)$, but far from those recorded by Gallego et al., (2014) $\left(2,531 \mathrm{kcal} \mathrm{kg}^{-1}\right)$ 
and Carvalho et al., (2012) (4,555 kcal kg-1). The ME glycerin values found in this study are close to that of corn, about 3,340 $\mathrm{kcal} \mathrm{kg}^{-1}$ (Rostagno et al., 2011), reinforcing the assertion that glycerin can be used in the feed of pigs as an energy source. The energy content of glycerin is dependent on its composition, especially in terms of glycerol and fatty acids, which are inversely proportional and related to their efficiency of production (Kerr et al., 2009). Gott and Eastridge (2010), analyzing sixteen samples of glycerin obtained from different raw materials and industries, stated that the ash content has a wide variation in the chemical composition, due to the quantum of catalysts used in each industry. Oliveira et al. (2013), analyzing 41 samples of glycerin from sixteen biodiesel plants in Brazil, registered $304-901 \mathrm{~g} \mathrm{~kg}^{-1}$ glycerol levels, $0-377 \mathrm{~g} \mathrm{~kg}^{-1}$ total fat levels, and $2.3-12.1 \%$ mineral matter levels, which demonstrated higher variation.

The energy content of glycerin is related to its metabolism, which is based on the fact that glycerol from the diet is absorbed by passive diffusion (Pluske, 2007) and is turned into glucose in the liver via phosphorylation to glycerol-3-phosphate (Mourot et al., 1994); however, an excess will be excreted in the urine (Oliveira et al., 2014), indicative of saturation of the metabolic pathways of glycerol due to the limitation of the glycerin conversion to glycerine-3-phosphate by the key liver enzyme glycerin kinase. However, Papadomichelakis et al. (2012) found that glycerol kinase mRNA expression in liver of pigs increased linearly when the glycerin increased from 0 to $150 \mathrm{~g} \mathrm{~kg}^{-1}$ in the diet, indicating no saturation effect.

The ME:DE ratio was similar to the 0.96 reported by Lammers et al. (2008). This result ratifies that only $4.0 \mathrm{~g} \mathrm{~kg}^{-1}$ glycerin of the digestible energy is lost via urine. In their studies, Mendonza et al. (2010) stated that there is a limitation in the glycerin metabolism, because upon being absorbed, it is converted to glucose in the liver. Nevertheless, excess levels may exceed the liver metabolization capacity, causing it to be excreted in the urine. In their study with glycerin inclusion at $300 \mathrm{~g} \mathrm{~kg}^{-1}$, Mendonza et al. (2010) found higher urinary excretion in animals fed glycerin as compared with control-diet-fed animals, reaching a ME:DE ratio of 0.866 .

The $\mathrm{ME}_{\mathrm{N}}: \mathrm{DE}_{\mathrm{N}}$ values of glycerin were similar to those of the ME:DE ratio, which is an expected result, given that glycerin is an energy ingredient, and losses of energy fraction by the nitrogen balance are little relevant. According to Cerrate et al. (2006), glycerol may have effects on the retention of amino acids or nitrogen, benefiting the deposition of body protein through inhibition of the activity of the phosphoenolpyruvate carboxykinase and glutamate dehydrogenase enzymes, which participate in the protein metabolism. The $\mathrm{ME}_{\mathrm{N}}$ of the diet shows that the energy content lost through retained or excreted nitrogen was very low and that the protein contents of the diets interfered little with their energy content.

The lower $\mathrm{DE}, \mathrm{DE}_{\mathrm{N}}, \mathrm{ME}$, and $\mathrm{ME}_{\mathrm{N}}$ values of glycerin obtained with the marker method in relation to the total collection method suggest that chromium oxide was not fully recovered in the feces. In this regard, Zanella et al. (1999) explained that the low recovery rate of chromium oxide led to lower ME values than those obtained by total collection in a study with broilers. Although chromium oxide is largely utilized, Cortés et al. (2009) assumed that there might be variability among results due to the difficulty in reproducing them in some laboratories and the incomplete recovery of this marker from the feces, resulting in underestimated concentrations.

\section{Conclusions}

The glycerin obtained from soybean oil has 3,272 and $3,263 \mathrm{kcal} \mathrm{kg}^{-1}$ metabolizable energy as determined by the total collection and chromium oxide marker techniques, respectively. Levels up to $150.0 \mathrm{~kg}^{-1}$ of the test ingredient do not influence the determination of the digestible energy or metabolizable energy of glycerin. Inclusion of $150 \mathrm{~kg}^{-1}$ glycerin improves the digestibility coefficients of dry matter, organic matter, and energy of the diets. The digestibility assessment method using chromium oxide underestimates the digestibility coefficient of ash and the energy values of glycerin, but provides similar results to the total collection method for the other nutrients evaluated.

\section{Acknowledgments}

The authors thank Fundação de Amparo à Pesquisa do Estado de Mato Grosso (FAPEMAT) for the financial support for the research and the fellowship granted to the first author and Bunge Alimentos for donating the glycerin.

\section{References}

Adeola, O. and Ileleji, K. 2009. Comparison of two diet types in the determination of metabolizable energy content of corn distillers dried grains with soluble for broiler chickens by regression method. Poultry Science 88:579-585.

Agudelo, J. H.; Lindemann, M. D. and Cromwell, G. L. 2010. A comparison of two methods to assess nutrient digestibility in pigs. Livestock Science 133:74-77.

Carvalho, P. L. O.; Moreira, I.; Martins, E. N.; Piano, L. M.; Toledo, J. B. and Costa Filho, C. L. 2012. Crude glycerine in diets for piglets. Revista Brasileira de Zootecnia 41:1654-1661. 
Cerrate, S.; Yan, F.; Wang, Z.; Coto, C.; Sacakli, P. and Waldroup, P. W. 2006. Evaluation of glycerine from biodiesel production as a feed ingredient for broilers. Journal of Poultry Science 5:1001-1007.

Cortés, M. E. M.; Ribeiro, A. M. L.; Gianfelici, M. F.; Kessler, A. M. and Moraes, M. L. 2009. Study of methodological variations in apparent nutrient metabolism determination in broiler chickens. Revista Brasileira de Zootecnia 38:1921-1927.

Detmann, E.; Souza, M. A.; Valadares Filho, S. C.; Queiroz, A. C.; Berchielli, T. T.; Saliba, E. O. S.; Cabral, L. S.; Pina, D. S.; Ladeira, M. M. and Azevedo, J. A. G. 2012. Métodos para análise de alimentos. INCT - Ciência Animal. Suprema, Visconde do Rio Branco.

Fernandez, F.; Miquel, A. G.; Martinez, R.; Serra, E.; Guinea, J.; Narbaiza, F. J.; Caseras, A. and Baanante, I. V. 1999. Dietary chromic oxide does not affect the utilization of organic compounds but can alter the utilization of mineral salts in gilthead sea bream Sparus aurata. Journal of Nutrition 129:1053-1059.

Gallego, A. G.; Moreira, I.; Pozza, P. C.; Carvalho, P. L. O.; Sierra, L. M. P. and Costa Filho, C. L. 2014. Neutral semi-purified glycerin in starting pigs feeding. Semina: Ciências Agrárias 35:2831-2842.

Gobesso, A. A. O.; Ramos, S. C.; Casalech, F. L.; Moreira, A. M. F. O.; Brandi, R.A.; Rennó, F. P. and Freitas Junior, J. E. 2011. Indicadores para estimativa da digestibilidade aparente total em equinos. Revista Brasileira de Saúde e Produção Animal 12:264-274.

Gomide, A. P. C.; Brustolini, P. C.; Ferreira, A. S.; Paulino, P. V. R.; Lima, A. L.; Scottá, B. A.; Rodrigues, V. V.; Câmara, L. R. A.; Moita, A. M. S.; Oliveira Júnior, G. M.; Ferreira, R. C. and Formigoni, A. S. 2012. Substituição de milho por glicerina bruta em dietas para suínos em terminação. Arquivo Brasileiro de Medicina Veterinária e Zootecnia 64:1309-1316.

Gonçalves, L. M. P.; Moreira, I.; Furlan, A. C.; Carvalho, P. L. O.; Costa Filho, C. L. and Cruz, T. M. P. 2013. Semipurified glycerins on starting piglets feeding $(15-30 \mathrm{~kg})$. ActaScientiarum. Animal Sciences 35:159-164.

Gott, P. N. and Eastridge, M. L. 2010. Variation in the chemical composition of crude glycerin [Abstract]. p.153. In: Proceedings Tri-State Dairy Nutrition Conference. Ohio State University Extension, Columbus.

Groesbeck, C. N.; McKinney, L. J.; Derouchey, J. M.; Tokach, M. D.; Goodband, R. D.; Dritz, S. S.; Nelssen, J. L.; Duttlinger, A. W.; Fahrenholz, A. C. and Behnke, K. C. 2008. Effect of crude glycerol on pellet mill production and nursery pig growth performance. Journal of Animal Science 86:2228-2236.

Hanczakowska, E.; Węglarzy, K.; Beata Szymczyk, B. and Hanczakowski, P. 2010. Effect of adding crude or refined glycerol to pig diets on fattening performance, nutrient digestibility and carcass evaluation. Annals of Animal Science 10:67-73.

Hopper, J. T.; Holloway, J. W. and Butts Jr, W. T. 1978. Animal variation in chromiun sesquioxide excretion patterns of grazing cows. Journal of Animal Science 46:1098-1102.

Kavanagh, S.; Lynch, P. B.; O’Mara, F. and Caffrey, P. J. 2001. A comparison of total collection and marker technique for the measurement of apparent digestibility of diets for growing pigs. Animal Feed Science and Technology 89:49-58.

Kerr, B. J.; Weber, T. E; Dozier, W. A. and Kidd, M. T. 2009. Digestible and metabolizable energy content of crude glycerin originating from different sources in nursery pigs. Journal of Animal Science $87: 4042-4049$.

Lammers, P. J.; Kerr, B. J; Weber, T. E.; Dozier, W. A.; Kidd, M. T.; Bregendahl, K. and Honeyman, M. S. 2008. Digestible and metabolizable energy of crude glycerol for growing pigs. Journal of Animal Science 86:602-608.

Leite, R. G.; Corassa, A.; Ton, A. P. S.; Komiyama, C. M.; Amorim, A. B. and Kiefer, C. 2017. Glycerin levels while maintaining the electrolyte balance in finishing pig diets. Revista Brasileira de Zootecnia 46:211-217.
Madrid, J.; Villodre, C.; Valera, L.; Orengo, J.; Martinez, S.; López, M. J.; Megias, M. D. and Hernandez, F. 2013. Effect of crude glycerin on feed manufacturing, growth performance, plasma metabolites, and nutrient digestibility of growing-finishing pigs. Journal of Animal Science 91:3788-3795.

Mendonza, O. F.; Ellis, M.; McKeith, F. K. and Gaines, A. M. 2010. Metabolizable energy content of refined glycerin and its effects on growth performance, and carcass and pork quality characteristics of finishing pigs. Journal of Animal Science 88:3887-3895.

Mourot, J.; Aumaitre, A.; Mounier, A.; Peiniau, P. and Fracois, A. C. 1994. Nutritional and physiological effects of dietary glycerol in the growing pig: consequences on fatty tissues and postmortem muscular parameters. Livestock Production Science 38:237-244.

Nunes, A. N. 2012. Validação de técnicas instrumentais para quantificação de amido e indicadores de digestibilidade para dietas suínos em crescimento. Dissertação (M.Sc.). Universidade Federal de Minas Gerais, Belo Horizonte.

Oliveira, J. S.; Antoniassi, R.; Freitas, S. C. and Muller, M. D. 2013. Composição química da glicerina produzida por usinas de biodiesel no Brasil e potencial de uso na alimentação. Ciência Rural 43:509-512.

Oliveira, L.; Madrid, J.; Ramis, G.; Martínez, S.; Orengo, J.; Villodre, C.; Valera, L.; López, M. J.; Pallarés, F. P.; Quereda, J. J.; Mendonça, L. and Hernández, F. 2014. Adding crude glycerin to nursery pig diet: effect on nutrient digestibility, metabolic status, intestinal morphology and intestinal cytokine expression. Livestock Science 167:227-235.

Papadomichelakis, G.; Zoidis, E.; Mountzouris, K. C.; Lippas, T. and Fegeros, K. 2012. Glycerine kinase gene expression, nutrient digestibility and gut microbiota composition in post-weaned pigs fed diets with increasing crude glycerine levels. Animal Feed Science and Technology 177:247-252.

Pluske, J. 2007. Evaluation of glycerine as a coproduct of biodiesel production for the pig industry. Technical Report for Pork Cooperative Research Centre. SciEcons Consulting. Available at: $<$ http://www.apri.com.au/1C-101_Glycerine_report.pdf $>$. Accessed on: Jan. 31, 2017.

Ribeiro Filho, H. M. N.; Zimermann, F. C. and Kozloski, G. V. 2008. Baixa dosagem de óxido de cromo para estimativa da produção fecal em bovinos. Ciência Rural 38:2567-2578.

Rocha, L. O. 2013. Glicerina bruta na alimentação de suínos nas fases pré inicial e inicial. Tese (D.Sc.). Universidade Federal de Goiás, Goiânia.

Rostagno, H. S.; Albino, L. F. T.; Donzele J. L.; Gomes, P. C.; Oliveira, R. F.; Lopes, D. C.; Ferreira, A. S.; Barreto, S. L. T. and Euclides, R. F. 2011. Tabelas brasileiras para aves e suínos: composição de alimentos e exigências nutricionais. UFV, Viçosa, MG.

Sakomura, N. K. and Rostagno, H. S. 2007. Métodos de pesquisa em nutrição de monogástricos. FUNEP, Jaboticabal.

Soares, L. P. G.; Berchielli, T. T.; Aroeira, L. J. M.; Deresz, F. and Verneque, R. S. 2004. Estimativas de consumo do capim-elefante (Pennisetum purpureum Schum), fornecido picado para vacas lactantes utilizando a técnica do óxido crômico. Revista Brasileira de Zootecnia 33:811-820.

Verussa, G. H.; Corassa, A.; Pina, D. S.; Ton, A. P. S.; Komiyama, C. M. and Teixeira, A. O. 2017. Performance and serum parameters of growing pigs fed diets containing semipurified glycerin. Revista Colombiana de Ciencias Pecuarias 30:11-20.

Zanella, I.; Sakomura, N. K.; Silversides, F. G.; Figueiredo, A. and Pack, M. 1999. Effect of enzyme supplementation of broiler diets based on corn and soybeans. Poultry Science 78:561-568.

Zijlstra, R. T.; Menjivar, K.; Lawrence, E. and Beltranena, E. 2009.The effect of feeding crude glycerol on growth performance and nutrient digestibility in weaned pigs. Journal of Animal Science 89:85-89. 